\title{
PENERAPAN MODEL PEMBELAJARAN TWO STAY-TWO STRAY PADA MATA PELAJARAN PENDIDIKAN PANCASILA DAN KEWARGANEGARAAN DI KELAS X AP 2 SMK PASUNDAN 1 KOTA SERANG
}

\author{
Ade Millatus Sa'adiyyah', Diana Sekar Anggraini' ${ }^{2}$, Dedeh Novita Sari ${ }^{3}$ \\ Universitas Banten Jaya \\ Serang, Indonesia \\ Ade.Millatus@gmail.com ${ }^{1}$, Dianasekaranggraini@unbaja.ac.id ${ }^{2}$, \\ Dedehnovitasari01@gmail.com ${ }^{3}$
}

\begin{abstract}
ABSRACT
The research problem of this class action is the low motivation to learn civics class X AP 2 SMK Pasundan! City of Serang in the academic year 2017. The purpose of this research is to increase student' motivation on the subjects of civic education. The results of this research can be direct benefit to the school is to improve the quality of civic educatin, besides that it is also useful for teachers and students. This reseach implemented in three cycles, where each cycle includes the activites of planning, action, observation, and reflection. Teh subjects of the research ar student of class X AP 2 as man as 46 student. The troubleshoothing method used is to apply cooperative learning model Two Stay - Two Stray on the subjects of civic education, the instrumens of the research is using observation sheet increase student motivation and field notes, implementation of the research conducted collaboratively wiht teachers as obsever and researchers act ang implementers. The results of this research show increased student motivation. The cycle I with an average of 40, $10 \%$ the cycle II with an avarege 57,82\% The cycle III with an avarage of $81,95 \%$ There fore this classroom action research is successful so the researchers recommended the implementation of learning model Two Stay - Two Stray can increase student's motivation on the subjects of civic education.
\end{abstract}

Keywords : Learning model, Two stay two stray, Civic education

\section{PENDAHULUAN}

Sekolah memiliki peranan dan tanggung jawab yang sangat penting dalam mempersiapkan warga negara yang memiliki komitmen kuat dan konsisten untuk mempertahankan Negara Kesatuan Republik Indonesia. Menurut winataputra (2008, hlm.118) dalam pendidikan perlu diperhatikannya pembelajaran karena pada dasarnya pembelajaran merupakan salah satu kunci utama dalam mencapai tujuan pendidikan, pembelajaran yang baik adalah pembelajaran yang berlangsung secara efektif dan efisien sehingga dapat mencapai suatu tujuan"pembelajaran merupakan kegiatan yang dilakukan untuk menginisiasi, memfasilitasi, dan meningkatkan intensitas dan kualitas belajar pada diri siswa.Dalam kegiatan belajar, motivasi merupakan keseluruhan daya penggerak di dalam diri yang menimbulkan kegiatan belajar yang menjamin kelangsungan dari kegiatan belajar. Oleh sebab itu, diperlukan perangkat tertentu untukdapat mengikat informasi yang baru saja diterima dari guru. 
Belajar aktif adalah salah satu cara untuk mengikat informasi yang baru kemudian menyimpannya dalam otak. Namun berdasarkan pengamatan peneliti di kelas $\mathrm{X}$ AP 2 SMK pasundan 1 kota serang, masih ditemukan masalah-masalah pada mata pelajaran pendidikan sedang menerangkan, siswa merasa bosan didalam kelas, pembelajaran yang terasa monoton, siswa tidak semangat dalam belajar, siswa bermalas-malasan dalam mengerjakan tugas, siswa kurang tertarik dalam pembelajaran pendidikan pancasila dan kewarganegaraan, siswa kurang aktif bertanya bahkan tidak menjawab ketika guru bertanya, kurangnya kemampuan siswa dalam menganalisis, siswa tidak berani mengungkapkan pendapat secara individu atau kelompok, suasana pembelajaran dikelas cenderung pasif akibatnya siswa kurang berperan aktif dalam proses pembelajaran.

Berdasarkan masalah di atas, dapat dikatakan bahwa motivasi belajar siswa dalam proses pembelajaran pendidikan pancasila dan kewarganegaraan cenderung rendah. Menurut Hamzah B. Uno dan Nurdin Mohamad (2015:253), indikator motivasi adalah Tekun menghadapi tugas, Ulet menghadapi kesulitan, Tidak memerlukan dorongan dari luar untuk berprestasi, Ingin mendalami bahan atau bidang pengetahuan yang diberikan., Selalu berusaha berprestasi sebaik mungkin, Menunjukkan minat terhadap macam-macam masalah orang dewasa, Senang dan rajin belajar, penuh semangat, cepat bosan dengan tugas-tugas rutin, dapat memperhatankan pendapatpendapatnya, Mengejar tujuan-tujuan jangka panjang, Senang mencari dan memecahkan soal.

Suryabrata (2015, hlm. 06) membedakan motif menjadi dua, yakni motif-motif ekstrinsik dan motif-motif intrinsik:Motif Ekstrinsik, yaitu motif-motif yang berfungsinya karena adanya perangsangan dari luar, misalnya orang belajar giat karena diberi tahu bahwa sebentar lagi aka nada ujian, orang membaca sesuatu karena diberi tahu bahwa hal itu harus dilakukannya sebelum ia dapat melamar pekerjaan, dan sebagainya. Motif Intrinsik, yaitu motif-motif yang berfungsinya tidak perlu dirangsang dari luar. Memang dalam diri individu sendiri telah ada dorongan itu.Misalnya orang yang gemar membaca tidak usah ada yang mendorongnya telah mencari sendiri bukubuku untuk dibacanya, orang yang rajin dan bertanggung jawab tidak usah menanti komando sudah belajar secara sebaikbaiknya.

Salah satu usaha untuk memperbaiki proses pembelajaran tersebut adalah dengan 
menggunakan model pembelajaran Two StayTwo Stray (Dua Tinggal Dua Tamu). Model pembelajaran kooperatif dua tinggal dua tamu adalah dua orang siswa tinggal di kelompok dan dua orang siswa bertemu ke kelompok lain. Dua orang yang tinggal bertugas memberikan informasi kepada tamu tentang hasil kelompoknya, sedangkan yang bertemu bertugas mencatat hasil diskusi kelompok yang dikunjunginya. Lie, (2012:221).

Disini penulis menggunakan model pembelajaran Two Stay-Two Stray (Dua Tinggal Dua Tamu), yang diharapkan dapat membuat motivasi belajar siswa terhadap mata pelajaran pendidikan pancasila dan kewarganegaraan menjadi meningkat, menyenangkan dan tidak membosankan lagi. Maka penulis mangadakan penelitian dengan judul "Penerapan Model Pembalajaran Two Stay-Two Stray (Dua Tinggal Dua Tamu)untuk meningkatkan motivasi belajar siswa pada Mata Pelajaran Pendidikan Pancasila dan Kewarganegaraan.

\section{METODE PENELITIAN}

Dalam penelitian ini penulis mengambil lokasi SMK pasundan 1 kota serang pada semester II tahun pelajaran 2016-2017. Subjek penelitian dalam penelitian ini adalah siswa/siswi kelas X AP 2 SMK pasundan 1 kota serang. Jumlah siswa 46 orang.terdiri dari 5 siswa laki-laki dan 41 siswa perempuan. Pertimbangan penulis mengambil subjek penelitian tersebut dimana siswa kelas $\mathrm{X}$ AP 2 belum mampu mengikuti kegiatan belajar dengan baik. Waktu penelitian pada semester II tahun pelajaran 2016-2017 dari tanggal 08 sampai 22 April Kegiatan penelitian meliputi kegiatan persiapan sampai akhir pelaksanaan.

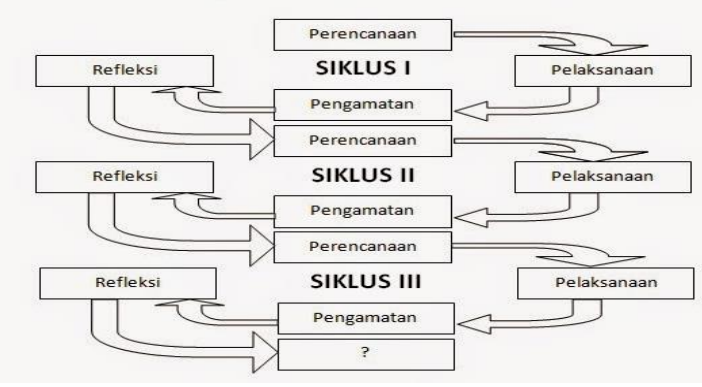

Gambar 1. Alur Penelitian Tindakan Kelas menurut Model Kemmis, Mc.Taggar (Rusna Ristasa, 2007:7)

Teknik pengumpulan data pada penelitian ini yang digunakan adalah Observasi dokumentasi, wawancara.

Indikator Keberhasilan dalam penelitian ini yaitu sebagai tolak ukur meningkatkan motivasi belajar siswa pada mata pelajaran pendidikan pancasila dan kewarganegaraan melalui model pembelajaran Two Stay-Two Stray (Dua Tinggal Dua Tamu) dapat di lihat dari hasil Kriteria Ketuntasan Minimal (KKM) belajar siswa yaitu 75 dan juga dilihat 
dari indikator-indikator motivasi yang dicapai oleh siswa dengan nilai yaitu $81,95 \%$.

Teknik analisis data yang peneliti lakukan untuk meningkatkan motivasi belajar siswa di sekolah yaitu dengan menggunakan pendekatan keabsahan data hasil belajar siswa yaitu Reduksi data, Display data , mengambil Kesimpulan dan Verifikasi Data.

Dalam penelitian ini peneliti melakukan kolaborasi bersama dengan guru pendidikan pancasila dan kewarganegaraan kelas X AP 2 SMK pasundan 1 kota serang yang bernama Nina Rahmawati, S.Pd. Peneliti sebagai pelaksana dan guru sebagai perencana atau observer kegiatan pembelajaran dan mengawasi jalannya kegiatan pembelajaran.

\section{HASIL PENELITIAN DAN PEMBAHASAN}

Sesuai dengan rencana yang telah disusun diawal, pada proses pembelajaran pendidikan pancasila dan kewarganegaraan di setiap siklusnya peneliti menggunakan model pembelajaran Two Stay-Two Stray (Dua Tinggal Dua Tamu).

Pada siklus ke I dalam penelitian tindakan kelas X AP 2 SMK Pasundan 1 kota serang dilaksanakan pada hari sabtu tanggal 08 April 2017, pada pukul 11.15-12.30 WIB, dengan alokasi waktu $2 \times 45$ menit, pada pertemuan ini terdiri dari empat tahapan, yaitu tahap perencanaan, tahap pelaksanaan, tahap observsai, dan tahap refleksi. Berikut adalah uraian dari tiap-tiap tahapan yang akan dilaksanakan:

Pada tahap perencanaan peneliti mempersiapkan perangkat pembelajaran seperti silabus, RPP, ringkasan materi, soal evaluasi, dan penelitian tindakan kelas ini meliputi lembar aktivitas siswa dan guru dalam pembelajaran dan pengumpulan data motivasi belajar siswa. Cara mengetahui ataupun penilaian motivasi belajar siswa dilakukan dengan menggunakan lembar observasi motivasi siswa dalam proses pembelajaran.

Maka peneliti akan menjelaskan secara terperinci apa saja yang menjadi kegiatan didalam tahap perencanaan ini, yaitu: Membuat silabus sebagai rencana pembelajaran pada mata pelajaran pendidikan pancasila dan kewarganegaraan dengan tema tertentu yang mencakup standar kompetensi, kompetensi dasar, materi pokok pembelajaran, kegiatan pembelajaran, indikator, penilaian, alokasi waktu, dan sumber, bahan, alat belajar. Menyiapkan RPP dengan menggunakan model pembelajaran Two Stay -Two Stray (Dua Tinggal Dua Tamu) sebagai rencana yang menggambarkan prosedur dan pengorganisasian pembelajaran 
untuk mencapai satu kompetensi dasar yang ditetapkan dalam Standar Isi dan dijabarkan dalam silabus.Membuat ringkasan materi yang mencakup poin-poin yang dianggap penting sesuai dengan materi yang akan disampaikan. Membuat perangkat penilaian yang berupa lembar observasi untuk mengamati lembar penilaian aktivitas siswa, lembar instrumen motivasi dan lembar penilaian aktivitas guru selama proses pembelajaran dengan menggunakan model pembelajaran Two Stay -Two Stray (Dua Tinggal Dua Tamu) di kelas X AP 2

Selanjutnya adalah tahap pelaksanaan. Tahap ini merupakan merupakan kegiatan utama peneliti, yaitu dilaksanakannya rencana pembelajaran yang telah direncanakan sebelumnya pelaksanaan peneliti tindakan siklus I ini dilaksanakan pada hari sabtu tanggal 08 April 2017 pada pukul 11.15-12.30 WIB dengan alokasi waktu 2x45 menit. Didalam pertemuan yang pertama, peneliti menyajikan materi BAB VI Ancaman terhadap Negara dalam Membangun Integrasi Nasional sub bab A Ancaman, Tantangan, Hambatan, dan Gangguan Integrasi Nasional.Didalam pelaksanaan, peneliti bertindak sebagai guru peneliti dan diamati oleh Nina Rachmawati, S.Pd selaku guru mitra mata pelajaran pendidikan pancasila dan kewarganegaraan di kelas X AP 24 SMK Pasundan 1 kota serang. Kegiatan awal guru mengucapkan salam, Guru mempersiapkan kerapihan dan kebersihan ruang kelas, presensi (kehadiran, kebersihan kelas, menyiapkan media dan alat serta bahan ajar). Guru memberikan pertanyaan lisan tentang materi yang ingin dipelajari untuk mendapatkan gambaran kesiapan belajar peserta didik dan dilanjutkan dengan menyampaikan topik tentang Ancaman, Tantangan, Hambatan, dan Gangguan Integrasi Nasional.

Selanjutnya adalah kegiatan inti. Guru memberikan penjelasan mengenai materi Ancaman, Hantangan, Hambatan, dan Gangguan Integrasi Nasional. Guru mempersilahkan peserta didik untuk bertanya mengenai materi hakikat Ancaman, Hantangan, Hambatan, dan Gangguan Integrasi Nasional. Guru membagi siswa dalam beberapa kelompok yang masingmasing kelompok beranggotakan 4 orang dan guru memberikan tugas kepada peserta didik mengenai materi yang baru saja diajarkan untuk dikerjakan oleh siswa. Kegiatan kelompok pada kegiatan ini pembelajaran menggunakan lembar kegiatan yang berisi tugas-tugas yang harus dipelajari oleh tiaptiap siswa dalam satu kelompok. Setelah menerima lembar kegiatan yang berisi 
permasalahan-permasalahan yang berkaitan dengan konsep materi, siswa mempelajarinya dalam kelompok kecil 4 orang siswa, yaitu mendiskusikan masalah tersebut bersamasama anggota kelompoknya.Masingmasingkelompokmenyelesaikan atau memecahkan masalah yang diberikan dengan cara mereka sendiri. Kemudian 2 dari 4 anggota dari masing-masing kelompokmeninggalkan kelompoknya dan bertemu ke kelompok yang lain, sementara 2 anggota yang tinggal dalam kelompok bertugas menyampaikan hasil kerja dan informasi mereka ke tamu mereka. Setelah memperoleh informasi dari 2 anggota yang tinggal, tamu mohon diri dan kembali ke kelompok masing-masing dan melaporkan temuannya serta mencocokan dan membahas hasil-hasil kerja mereka.

Formalisasi setelah belajar dalam kelompok dan menyelesaikan permasalahan yang diberikan salah satu kelompok mempresentasikan hasil diskusi kelompoknya untuk di komunikasikan atau didiskusikan dengan kelompok lainnya. Kemudian guru membahas dan mengarahkan siswa ke bentuk formal.

Dan yang terakhir pada kegiatan inti adalah evaluasi kelompok dan penghargaan. Pada tahap evaluasi ini untuk mengetahui seberapa besar kemampuan siswa dalam memahami materi yang telah diperoleh dengan menggunakan model pembelajaran Two StayTwo Stray (Dua Tinggal Dua Tamu). Masingmasing siswa diberi kuis yang berisi pertanyaan-pertanyaan dari awal pembelajaran dengan model Two Stay-Two Stray (Dua Tinggal Dua Tamu) yang selanjutnya dilanjutkan dengan pemberian penghargaan kepada kelompok yang mendapatkan skor rat-rata tertinggi.

Kegiatan terakhir adalah kegiatan penutup. Guru mengulas kembali materi pelajaran dan mengkonfirmasi kegiatan individu dan kelompok. Peserta didik ditanya apakah sudah memahami materi tersebut. Peserta didik ditanya tentang nilai-nilai apa saja yang didapat dari pelajaran hari ini.

Tahapan berikutnya pada penelitian tindakan kelas siklus I ini adalah tahapan observasi. Pada tahap penerapan siklus I ini melakukan pengamatan atau observasi dengan menggunakan lembar-lembar observasi yang telah di siapkan, yakni meliputi lembar observasi aktivitas siswa, aktivitas guru, lembar instrument motivasi belajar. Dari hasil observasi yang dikumpulkan hasilnya masih kurang memuaskan karena masih banyak siswa yang belum paham dalam langkah-langkah model pembelajaran Two Stay-Two Stray (Dua Tinggal Dua Tamu), suasana kelaspun tidak 
kondusif karena masih banyak siswa yang ngobrol dan bercanda.

Sehubungan dengan hasil observasi yang dikumpulkan dengan kemudian diamati ternyata aktivitas siswa belum mencapai kriteria yang baik dengan apa yang diinginkan yaitu aktivitas siswa minimal atau dalam kategori kurang.

Dapat di simpulkan bahwa kemampuan siswa dalam proses pembelajaran masih sangat kurang sebagaimana terlihat dari hasil yang diperoleh adalah 52,5\% dari kriteria yang diharapkan karena masih banyak kegiatan siswa selama proses pembelajaran belum berjalan dengan baik.

Berdasarkan dari analisa data yang telah diamati dari penelitian yang dilakukan bahwa pada siklus I setiap individu atau kelompok menyelesaikan tugas tersebut dengan kategori cukup terlihat dari hasil dan motivasi belajar siswa. Dapat dismpulkan bahwa ternyata hasil lembar observasi motivasi peserta didik belum mencapai kriteria yang diinginkan yaitu dimana hasil pada siklus I nilai motivasi peserta didik $40,10 \%$ termasuk dalam kategori cukup baik.

Dari hasil yang diperoleh secara keseluruhan cara mengajar yang dilakukan oleh peneliti dalam menerapkan model pembelajaran Two Stay-Two Stray (Dua Tinggal Dua Tamu) pada kegiatan guru dalam proses pembelajaran dilaksanakan pada siklus I beberapa aspek yang diamati hanya masuk dalam kategori kurang

Pada observasi cara mengajar yang dilakukan oleh peneliti pada saat proses pembelajaran dilaksanakan pada siklus I dari 10 aspek yang diamati hanya 37,5\%.

Dari pelaksanaan tindakan dan observasi yang dilakukan selanjutnya mengadakan refleksi untu memperbaiki masalah-masalah yang terdapat pada siklus berdasarkan pembelajaran pada siklus I dan untuk melaksanakan ke siklus berikutnya.

Berdasarkan tindakan pembelajaran siklus I yang telah dilakukan, peneliti menemukan beberapa permasalahan yang muncul selama proses pembelajaran berlangsung. Berikut dideskripsikan masalahmasalah yang masih muncul selama tindakan siklus I sebagai berikut: Guru tidak menjelaskan materi yang akan datang; Guru tidak mengecek kesiapan peserta didik; Pada siklus I hasil motivasi cukup, dari hasil yang diamati hanya mencapai pada skor rata-rata; Masih banyak siswa yang belum paham pada langkah-langkah penerapan model Two StayTwo Stray (Dua Tinggal Dua Tamu); dan kelas tidak kondusif serta masih banyak siswa masih ngobrol dan bercanda.

Pelaksanaan Siklus II. Pada siklus tindakan kedua ini merupakan siklus yang di 
ulang kembali dari siklus sebelumnya hal ini dimaksud untuk memperbaiki kekurangan yang terjadi pada pembelajaran siklus I. Pada siklus II ini dalam penelitian tindakan kelas $\mathrm{X}$ AP 2 SMK Pasundan 1 kota serang dilaksanakan pada hari sabtu tanggal 15 April 2017, pada pukul 11.15-12.30 WIB, dengan alokasi waktu $2 \times 45$ menit, pada pertemuan ini terdiri dari empat tahapan, yaitu tahap perencanaan, tahap pelaksanaan, tahap observsai, dan tahap refleksi. Berikut adalah uraian dari tiap-tiap tahapan yang akan dilaksanakan:

Tahap Perencanaan. Pada tahap perencanaan peneliti mempersiapkan perangkat pembelajaran seperti silabus, RPP, ringkasan materi, soal evaluasi, dan penelitian tindakan kelas ini meliputi lembar aktivitas siswa dan guru dalam pembelajaran dan pengumpulan data motivasi belajar siswa. Cara mengetahui ataupun penilaian motivasi belajar siswa dilakukan dengan menggunakan lembar observasi motivasi siswa dalam proses pembelajaran.

Maka peneliti akan menjelaskan secara terperinci apa saja yang menjadi kegiatan didalam tahap perencanaan ini, yaitu:

Pertama, membuat silabus sebagai rencana pembelajaran pada mata pelajaran pendidikan pancasila dan kewarganegaraan dengan tema tertentu yang mencakup standar kompetensi, kompetensi dasar, materi pokok pembelajaran, kegiatan pembelajaran, indikator, penilaian, alokasi waktu, dan sumber, bahan, alat belajar.

Kedua, Menyiapkan RPP dengan menggunakan model pembelajaran Two Stay -Two Stray (Dua Tinggal Dua Tamu) sebagai rencana yang menggambarkan prosedur dan pengorganisasian pembelajaran untuk mencapai satu kompetensi dasar yang ditetapkan dalam Standar Isi dan dijabarkan dalam silabus.

Ketiga, membuat ringkasan materi yang mencakup poin-poin yang dianggap penting sesuai dengan materi yang akan disampaikan.

Keempat, membuat perangkat penilaian yang berupa lembar observasi untuk mengamati lembar aktivitas siswa, lembar instrumen motivasi dan lembar aktivitas guru selama proses pembelajaran dengan menggunakan model pembelajaran Two Stay -Two Stray (Dua Tinggal Dua Tamu) di kelas X AP 2

Tahap Pelaksanaan. Tahap ini merupakan merupakan kegiatan utama peneliti, yaitu dilaksanakannya rencana pembelajaran yang telah direncanakan sebelumnya pelaksanaan peneliti tindakan siklus II dilaksanakan pada hari sabtu tanggal 15 April 2017 pada pukul 11.15-12.30 WIB dengan alokasi waktu 2x45 menit. Dalam pelaksanaan siklus II difokuskan pada 
pembelajaran dengan indikator materi $\mathrm{BAB}$ VI menganalisa Ancaman terhadap Negara dalam Membangun Integrasi Nasional bagian 3 Bentuk-bentuk Ancaman dalam pelaksanaan, peneliti bertindak sebagai guru peneliti dan diamati oleh Nina Rachmawati, S.Pd selaku guru mitra mata pelajaran pendidikan pancasila dan kewarganegaraan di kelas X AP 24 SMK Pasundan 1 kota serang. Proses pembelajaran ini dimulai dengan beberapa tahapan, yaitu:

Kegiatan awal. Guru mengucapkan salam, Guru mempersiapkan kelas kerapihan dan kebersihan ruang kelas, presensi (kehadiran, kebersihan kelas, menyiapkan media dan alat serta bahan ajar), Guru memberikan motivasi kepada peserta didik dan mengkomunikasikan tujuan pembelajaran yang ingin dicapai, Guru memberikan pertanyaan lisan tentang materi yang ingin dipelajari untuk mendapatkan gambaran kesiapan belajar peserta didik dan dilanjutkan dengan menyampaikan topik tentang Ancaman, Tantangan, Hambatan, dan Gangguan Integrasi Nasional.

Kegiatan Inti. Guru memberikan penjelasan mengenai materi Ancaman, Hantangan, Hambatan, dan Gangguan Integrasi Nasional, Guru mempersilahkan peserta didik untuk bertanya mengenai materi hakikat Ancaman, Hantangan, Hambatan, dan
Gangguan Integrasi Nasional, Guru membagi siswa dalam beberapa kelompok yang masing-masing kelompok beranggotakan 4 orang dan guru memberikan tugas kepada peserta didik mengenai materi yang baru saja diajarkan untuk dikerjakan oleh siswa, Kegiatan kelompok pada kegiatan ini pembelajaran menggunakan lembar kegiatan yang berisi tugas-tugas yang harus dipelajari oleh tiap-tiap siswa dalam satu kelompok. Setelah menerima lembar kegiatan yang berisi permasalahan-permasalahan yang berkaitan dengan konsep materi, siswa mempelajarinya dalam kelompok kecil 4 orang siswa, yaitu mendiskusikan masalah tersebut bersama-sama anggota kelompoknya. Masing-masing kelompok menyelesaikan atau memecahkan masalah yang diberikan dengan cara mereka sendiri. Kemudian 2 dari 4 anggota dari masingmasing kelompok meninggalkan kelompoknya dan bertemu ke kelompok yang lain, sementara 2 anggota yang tinggal dalam kelompok bertugas menyampaikan hasil kerja dan informasi mereka ke tamu mereka. Setelah memperoleh informasi dari 2 anggota yang tinggal, tamu mohon diri dan kembali ke kelompok masing-masing dan melaporkan temuannya serta mencocokan dan membahas hasil-hasil kerja mereka. 
Formalisasi setelah belajar dalam kelompok dan menyelesaikan permasalahan yang diberikan salah satu kelompok mempresentasikan hasil diskusi kelompoknya untuk di komunikasikan atau didiskusikan dengan kelompok lainnya. Kemudian guru membahas dan mengarahkan siswa ke bentuk formal, Evaluasi kelompok dan penghargaan pada tahap evaluasi ini untuk mengetahui seberapa besar kemampuan siswa dalam memahami materi yang telah diperoleh dengan menggunakan model pembelajaran Two Stay-Two Stray (Dua Tinggal Dua Tати). Masing- masing siswa diberi kuis yang berisi pertanyaan-pertanyaan dari awal pembelajaran dengan model Two Stay-Two Stray (Dua Tinggal Dua Tamu) yang selanjutnya dilanjutkan dengan pemberian penghargaan kepada kelompok yang mendapatkan skor rat-rata tertinggi.

Kegiatan Penutup. Guru mengulas kembali materi pelajaran dan mengkonfirmasi kegiatan individu dan kelompok, Peserta didik ditanya apakah sudah memahami materi tersebut, Peserta didik ditanya tentang nilai-nilai apa saja yang didapat dari pelajaran hari ini.

Peneliti pada tahap penerapan siklus II ini melakukan pengamatan atau observasi dengan cara menganalisis data sesuai dengan yang ada dari lembar-lembar observasi yang telah di siapkan, yakni meliputi lembar observasi penilaian aktivitas siswa, lembar observasi penilaian aktivitas guru dan lembar instrumen motivasi. Dari hasil observasi yang dikumpulkan hasilnya sudah mulai meningkat dari siklus I sebelumnya.

Sehubungan dengan hasil observasi yang dikumpulkan dengan kemudian diamati ternyata aktivitas siswa belum mencapai kriteria yang baik dengan apa yang diinginkan yaitu aktivitas siswa minimal atau dalam kategori cukup. Sedangkan untuk motivasi belajar siswa dinyatakan cukup terlihat dari masih banyaknya siswa bercanda, malu mengungkapkan pendapatnya dan takut salah dalam mempresentasikan hasil diskusi kelompok. Dapat simpulkan bahwa kemampuan siswadalam proses pembelajaran sudah mulai membaik dibandingkan dengan pertemuan sebelumnya sebagaimana terlihat dari hasil yang diperoleh adalah $77,5 \%$.

Berdasarkan dari analisa data yang telah amati dari penelitian yang dilakukan bahwa pada siklus II ini motivasi belajar siswa lebih meningkat dari pertemuan siklus sebelumnya dengan mendapatkan kategori cukup. Dari data hasil observasi yang dikumpulkan dan dianalisis ternayata hasil belajar ada peningkatan. Berdasarkan observasi atau pengamat didalam pelaksanaan siklus II 
pertemuan inipeneliti melakukan observasi atau pengamat berdasarkan motivasi belajar peserta didik dan berdasarkan observasi tersebut peneliti menarik kesimpulan bahwa motivasi peserta didik masih belum maksimal tetapi ada peningkatan dari pertemuan sebelumnya.Dari data di atas maka dapat di simpulkan bahwa motivasi belajar siswa dalam proses pembelajaran sudah mulai meningkat dari pertemuan sebelumnya dengan skor yang diperoleh adalah 57,82\% dikatakan baik jika dilihat dari kriteria keberhasilan siswa.

Dari hasil observasi yang diperoleh secara keseluruhan cara mengajar yang dilakukan peneliti dalam menerapkan model pembelajaran Two Stay-Two Stray (Dua Tinggal Dua Tamu) pada kegiatan guru dalam proses pembelajaran dilaksanakan pada siklus II ini aspek yang diamati hanya $50 \%$ maka dapat disimpulkan bahwa aktivitas guru sudah mulai meningkat dan mencapai kategori baik.

Dari pelaksanaan tindakan dan observasi dilakukan pada siklus II ini maka peneliti dan guru mengadakan refleksi untuk memperbaiki masalah-masalah yang terdapat pada siklus II untuk selanjutnya melaksanakan ke siklus berikutnya. Dapat dilihat dari indikator keberhasilan, rencana pembelajaran yang sudah tersampaikan, dengan nilai peserta didik yang sudah membaik dari siklus I, peneliti dan guru melakukan refleksi untuk menemukan peningkatan, diantaranya sebagai berikut : Guru juga sudah selalu menginformasikan materi yang akan diajarkan, Berdasarkan hasil observasi mengenai motivasi belajar peserta didik, masih banyak peserta didik belum terbiasa dengan kondisi belajar menggunakan model pembelajaran Two StayTwo Stray (Dua Tinggal Dua Tamu). Hal ini bisa dilihat dari hasil observasi terhadap motivasi belajar siswa dalam kegiatan belajar mengajar sudah mulai meningkat. Dan yang terakhir siswa sudah mulai memahami penerapan model Two Stay-Two Stray (Dua Tinggal Dua Tamu).

Pada siklus III ini dalam penelitian tindakan kelas X AP 2 SMK Pasundan 1 kota serang dilaksanakan pada hari sabtu tanggal 22 April 2017, pada pukul 11.15-12.30 WIB, dengan alokasi waktu 2x45 menit, pada pertemuan ini terdiri dari empat tahapan, yaitu tahap perencanaan, tahap pelaksanaan, tahap observsai, dan tahap refleksi. Berikut adalah uraian dari tiap-tiap tahapan yang akan dilaksanakan:

Tahap Perencanaan. Pada tahap perencanaan peneliti mempersiapkan perangkat pembelajaran seperti silabus, RPP, ringkasan materi, soal evaluasi, dan 
penelitian tindakan kelas ini meliputi lembar aktivitas siswa dan guru dalam pembelajaran dan pengumpulan data motivasi belajar siswa. Cara mengetahui ataupun penilaian motivasi belajar siswa dilakukan dengan menggunakan lembar observasi motivasi siswa dalam proses pembelajaran.

Maka peneliti akan menjelaskan secara terperinci apa saja yang menjadi kegiatan didalam tahap perencanaan ini, yaitu: Membuat silabus sebagai rencana pembelajaran pada mata pelajaran pendidikan pancasila dan kewarganegaraan dengan tema tertentu yang mencakup standar kompetensi, kompetensi dasar, materi pokok pembelajaran, kegiatan pembelajaran, indikator, penilaian, alokasi waktu, dan sumber, bahan, alat belajar, Menyiapkan RPP dengan menggunakan model pembelajaran Two Stay -Two Stray (Dua Tinggal Dua Tати) sebagai rencana yang menggambarkan prosedur dan pengorganisasian pembelajaran untuk mencapai satu kompetensi dasar yang ditetapkan dalam Standar Isi dan dijabarkan dalam silabus, Membuat ringkasan materi yang mencakup poin-poin yang dianggap penting sesuai dengan materi yang akan disampaikan, Membuat perangkat penilaian yang berupa lembar penilaian aktivitas siswa, lembar penilaian aktivitas guru, dan instrument motivasi selama proses pembelajaran dengan menggunakan model pembelajaran Two Stay -Two Stray (Dua Tinggal Dua Tamu) di kelas X AP 2.

Tahap Pelaksanaan. Tahap ini merupakan merupakan kegiatan utama peneliti, yaitu dilaksanakannya rencana pembelajaran yang telah direncanakan sebelumnya pelaksanaan peneliti tindakan siklus III ini dilaksanakan pada hari sabtu tanggal 22 April 2017 pada pukul 11.1512.30 WIB dengan alokasi waktu 2x45 menit. Didalam pertemuan yang pertama, peneliti menyajikan materi $\mathrm{BAB}$ VI Ancaman terhadap Negara dalam Membangun Integrasi Nasional sub bab B mengenai Bela Negara.

Didalam pelaksanaan, peneliti bertindak sebagai guru peneliti dan diamati oleh Nina Rachmawati, S.Pd selaku guru mitra mata pelajaran pendidikan pancasila dan kewarganegaraan di kelas X AP 24 SMK Pasundan 1 kota serang.

Proses pembelajaran ini dimulai dengan beberapa tahapan, yaitu:

Kegiatan awal. Guru mengucapkan salam, Guru mempersiapkan kelas kerapihan dan kebersihan ruang kelas, presensi (kehadiran, kebersihan kelas, menyiapkan media dan alat serta bahan ajar), Guru memberikan motivasi kepada peserta didik dan mengkomunikasikan tujuan pembelajaran yang ingin dicapai, Guru memberikan 
pertanyaan lisan tentang materi yang ingin dipelajari untuk mendapatkan gambaran kesiapan belajar peserta didik dan dilanjutkan dengan menyampaikan topik tentang Ancaman, Tantangan, Hambatan, dan Gangguan Integrasi Nasional.

Kegiatan Inti. Guru memberikan penjelasan mengenai materi Ancaman, Hantangan, Hambatan, dan Gangguan Integrasi Nasional, Guru mempersilahkan peserta didik untuk bertanya mengenai materi hakikat Ancaman, Hantangan, Hambatan, dan Gangguan Integrasi Nasional, Guru membagi siswa dalam beberapa kelompok yang masing-masing kelompok beranggotakan 4 orang dan guru memberikan tugas kepada peserta didik mengenai materi yang baru saja diajarkan untuk dikerjakan oleh siswa. Kegiatan kelompok pada kegiatan ini pembelajaran menggunakan lembar kegiatan yang berisi tugas-tugas yang harus dipelajari oleh tiap-tiap siswa dalam satu kelompok. Setelah menerima lembar kegiatan yang berisi permasalahan-permasalahan yang berkaitan dengan konsep materi, siswa mempelajarinya dalam kelompok kecil 4 orang siswa, yaitu mendiskusikan masalah tersebut bersama-sama anggota kelompoknya. Masing-masing kelompok menyelesaikan atau memecahkan masalah yang diberikan dengan cara mereka sendiri.
Kemudian 2 dari 4 anggota dari masingmasing kelompok meninggalkan kelompoknya dan bertemu ke kelompok yang lain, sementara 2 anggota yang tinggal dalam kelompok bertugas menyampaikan hasil kerja dan informasi mereka ke tamu mereka. Setelah memperoleh informasi dari 2 anggota yang tinggal, tamu mohon diri dan kembali ke kelompok masing-masing dan melaporkan temuannya serta mencocokan dan membahas hasil-hasil kerja mereka.

Formalisasi setelah belajar dalam kelompok dan menyelesaikan permasalahan yang diberikan salah satu kelompok mempresentasikan hasil diskusi kelompoknya untuk di komunikasikan atau didiskusikan dengan kelompok lainnya. Kemudian guru membahas dan mengarahkan siswa ke bentuk formal, dan yang terakhir adalah evaluasi kelompok dan penghargaan. Pada tahap evaluasi ini untuk mengetahui seberapa besar kemampuan siswa dalam memahami materi yang telah diperoleh dengan menggunakan model pembelajaran Two Stay-Two Stray (Dua Tinggal Dua Tamu). Masing- masing siswa diberi kuis yang berisi pertanyaanpertanyaan dari awal pembelajaran dengan model Two Stay-Two Stray (Dua Tinggal Dua Tamu) yang selanjutnya dilanjutkan dengan pemberian penghargaan kepada 
kelompok yang mendapatkan skor rat-rata tertinggi.

Kegiatan Penutup. Guru mengulas kembali materi pelajaran dan mengkonfirmasi kegiatan individu dan kelompok, Peserta didik ditanya apakah sudah memahami materi tersebut, Peserta didik ditanya tentang nilainilai apa saja yang didapat dari pelajaran hari ini.

Tahap Observasi. Peneliti pada tahap penerapan siklus III ini melakukan pengamatan atau observasi dengan menggunakan lembar-lembar observasi yang telah di siapkan, yakni meliputi lembar obsevasi aktivitas siswa, lembar instrumen motivasi belajar dan lembar observasi aktivitas guru . Dari hasil observasi yang dikumpulkan dan dianalisis ternyata bahwa motivasi peserta didik sudah mengalami peningkatan, maka didaptkan bahwa hasil pengamatan sebagai berikut:

Sehubungan dengan hasil observasi yang dikumpulkan dengan kemudian diamati ternyata aktivitas siswa mencapai kriteria yang baik dengan apa yang diinginkan yaitu aktivitas siswa masuk dalam kategori baik. Dapat dismpulkan bahwa ternyata hasil lembar observasi motivasi belajar peserta didik mencapai kriteria yang diinginkan yaitu dimana hasil pada siklus I ini nilai rata-rata motivasi peserta didik $95 \%$ termasuk dalam kategori baik.

Dari data hasil observasi yang dikumpulkan dan dianalisis ternayata hasil belajar ada peningkatan.Berdasarkan observasi atau pengamat didalam pelaksanaan siklus III peneliti melakukan observasi atau pengamat berdasarkan motivasi belajar peserta didik dan berdasarkan observasi tersebut peneliti menarik kesimpulan bahwa motivasi peserta didik meningkat sangat baik. Dari data di atas maka dapat di simpulkan bahwa motivasi belajar siswa dalam proses pembelajaran sudah mulai meningkat dari pertemuan sebelumnya dengan skor yang diperoleh adalah $81,95 \%$ dikatakan cukup jika dilihat dari kriteria keberhasilan siswa.

Dari hasil observasi yang diperoleh secara keseluruhan cara mengajar yang dilakukan oleh peneliti dalam menerapkan model pembelajaran Two Stay-Two Stray (Dua Tinggal Dua Tamu) pada kegiatan guru dalam proses pembelajaran dilaksankan pada siklus III ini dari aspek yang diamati 77,5\% maka disimpulkan bahwa guru sudah mulai meningkat dan mencapai kategori sangat baik

Tahap Refleksi. Berdasarkan hasil dari pelaksanaan siklus III ini maka peneliti dan guru melaksanakan refleksi untuk menemukan peningkatan diantaranya sebagai 
berikut: Guru sudah menyampaiakan kompetensi yang ingin dicapai, Guru sudah mengkondisikan kelas dan peserta didik sudah melakukan pengelolaan kelas dengan baik, Guru sudah menginformasikan materi yang akan diajarkan, Motivasi belajar siswa pada mata pelajaran pendidikan pancasila dan kewarganegaraan sudah sangat meningkat sangat baik.

Pada penelitian aktivitas siswa yang diamati pada saat pelaksanaan belajar mengajar berlangsung pada siklus I, siklus II dan siklus III diketahui bahwa setiap siklusnya selalu mengalami peningkatan setelah menggunakan model pembelajaran Two Stay-Two Stray (Dua Tinggal Dua Tати). Untuk mempermudah dalam melihat peningkatan aktivitas siswa setiap siklusnya dapat dilihat pada tabel berikut:

Tabel 1.

Rekapitulasi Penilaian Aktivitas Siswa Siklus I, Siklus II dan Siklus III

\begin{tabular}{|c|c|c|}
\hline No & Siklus dan Pertemuan & Nilai \\
\hline 1 & Aktivitas siswa pada siklus I & $52,5 \%$ \\
\hline 2 & Aktivitas siswa pada siklus II & $77,5 \%$ \\
\hline 3 & Aktivitas siswa pada siklus III & $95 \%$ \\
\hline
\end{tabular}

Tabel perbedaan data dari hasil penilaian aktivitas siswa di atas setiapsiklusnya selalu meningkat dengan baik, sehingga penelitian ini mengalami perubahan peningkatan penilaian aktivitas siswa pada setiap siklusnya, dimana perbedaan tersebut dapat dilihat pada grafik penilaian aktivitas siswa dibawah ini:

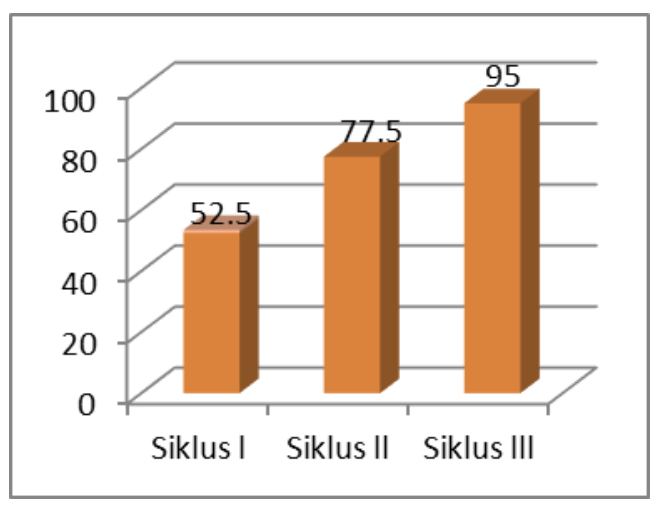

Gambar 2. Grafik penilaian aktivitas siswa siklus I, siklus II, dan siklus III

Grafik penilaian aktivitas siswa di atas dapat disimpulkan bahwa pada setiap siklus ternyata selalu mengalami peningkatan diamana siklus I masih tergolong kurang $52,5 \%$ dan pada siklus II mengalami peningkatan yaitu $77,5 \%$ kemudian mengalami peningkatan kembali dimana aktivitas siswa mencapai $95 \%$ setelah mata pelajaran pendidikan pancasila dan kewarganegaraan menggunakan model pembelajaran kooperatif tipe Two Stay-Two Stray (Dua Tinggal Dua Tamu).

Sedangkan pada penilaian instrumen motivasi yang diamati pada saat pelaksanaan belajar berlangsung pada siklus I, siklus II dan siklus III diketahui bahwa setiap siklusnya selalu mengalami peningkatan setelah menggunakan model pembelajaran 
Two Stay-Two Stray (Dua Tinggal Dua Тати). Untuk itu mempermudah dalam melihat peningkatan motivasi siswa setiap siklusnya dapat dilihat pada tabel berikut :

Tabel 2. Rekapitulasi Instrumen Penilaian Motivasi Siswa Siklus 1, Siklus II dan Siklus III

\begin{tabular}{lll}
\hline No & Siklus dan Pertemuan & Nilai \\
\hline 1 & Siklus I & $40,10 \%$ \\
2 & Siklus II & $57,82 \%$ \\
3 & Siklus III & $81,95 \%$ \\
\hline
\end{tabular}

Dilihat dari tabel diatas bahwa pada siklus I nilai rata-rata 40,10\% merupakan nilai dalam kategori cukup, dan pada nilai siklus II dengan nilai rat-rata $57,82 \%$ sudah mengalami perubahan yang cukup, sedangkan pada siklus III sudah mengalami perubahan baik karena niali rata-rata sudah mencapai $81,95 \%$ dikatakan baik kalau kita lihat dari kriteria keberhasilan siswa dan lulus dalam Kriteria Ketuntasan Minimal (KKM) yang ditentukan oleh SMK Pasundan 1 Kota Serang.

Adapun penilaian motivasi siswa pada siklus I, siklus II dan siklus III dapat dilihat pada grafik berikut:

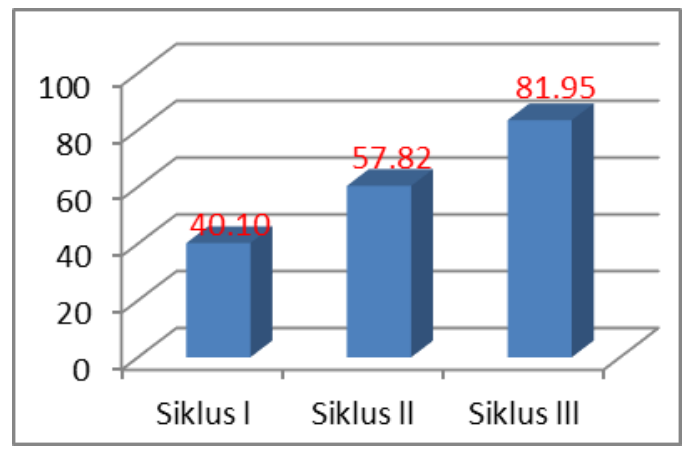

Gambar 3. Grafik penilaian motivasi siswa siklus I, siklus II, dan siklus III

Dari gambar diatas disimpulkan bahwa penilaian motivasi belajar siswa mengalami perubahan maupun peningkatan mulai dari siklus I yaitu 40,10\% ini dikatakan cukup jika kita lihat dari kriteria keberhasilan siswa, dan pada siklus II yaitu 57,82\% hal ini sudah terlihat ada peningkatan menjadi cukup baik, sedangkan pada siklus III sudah terlihat mengalami peningkatan yang sangat baik yaitu $81,95 \%$. Sedangkan pada penelitian aktivitas guru diamati pada saat pelaksanaan belajar mengajar berlangsung pada siklus I, siklus II dan siklus III diketahui bahwa setiap siklusnya selalu mengalami peningkatan setelah menggunakan model pembelajaran Two Stay-Two Stray (Dua Tinggal Dua Tати).

Sedangkan pada hasil penilaian terhadap aktivitas guru dengan melakukan pengamatan pada saat pelaksanaan belajar mengajar berlangsung seimbang dengan aktivitas siswa dimana selalu mengalami peningkatan 
dengan baik, hal tersebut bisa dilihat pada tabel berikut :

Tabel 3. Rekapitulasi Penilaian Aktivitas

Guru Siklus I, Siklus II dan Siklus III

\begin{tabular}{|c|c|c|}
\hline No & Siklus dan Pertemuan & Nilai \\
\hline 1 & Aktivitas guru pada siklus I & $37,5 \%$ \\
\hline 2 & Aktivitas guru pada sikulus II & $50 \%$ \\
\hline 3 & Aktivitas guru pada siklus III & $77,5 \%$ \\
\hline
\end{tabular}

Pada perbedaan hasil penelitian terhadap aktivitas guru dalam proses kegiatan belajar mengajar mengalami peningkatan, penilaian tersebut dapat dilihat pada grafik rekapitulasi penilaian terhadap aktivitas guru. Adapun penilaian aktivitas guru siklus I, siklus II dan siklus III dapat dilihat pada gambar berikut:

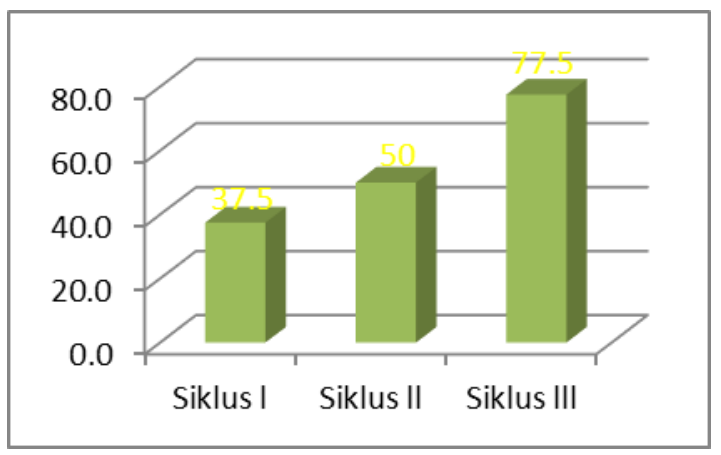

Gambar 4. Grafik penilaian aktivitas guru pada siklus I, siklus II, dan siklus III

Gambar hasil penelitian terhadap aktivitas guru di atas selama pelaksanaan belajar mengajar dapat disimpulkan bahwa setiap siklusnya mengalami peningkatan, pada siklus I mencapai $37,5 \%$, siklus II $50 \%$ dan mengalami peningkatan kembali dan pada siklus III yaitu $77,5 \%$ jadi bisa di garis bawahi bahwa aktivitas guru dalam kategori sangat baik, sehingga model pembelajaran tipe kooperatif Two Stay-Two Stray (Dua Tinggal Dua Tamu). Sudah layak untuk dikembangkan pada proses belajar mengajar di kelas X AP 2 SMK Pasundan 1 Kota Serang.

Dari hasil wawancara siswa di kelas $\mathrm{X}$ AP 2 SMK Pasundan 1 Kota Serang bahwa ada hambatan mengenai alokasi waktu dan solusi yang dapat dilakukan untuk mengatasi kendala dalam penerapan model pembelajaran Two Stay-Two Stray tersebut maka dalam pembelajaran materi dilaksanakan dua kali pertemuan supaya dalam menerapkan model pembelajaran tersebut bisa dilakukan dengan waktu yang cukup. Selanjutnya guru telah membagi waktu kegiatan tahapan-tahapan model Two Stay-Two Stray(Dua Tinggal Dua Tamu) dengan jelas dan proporsional, pembentukan kelompok sudah di buat oleh guru supaya dalam membagi kelompok siswa tidak ribut, rute perjalanan kelompok mana dulu yang akan dikunjungi misalnya searah jarum jam, guru menjelaskan dengan baik mengenai maksud dari tujuan bertamu, yaitu untuk menyimak presentasi dari kelompok tuan rumah, bukan sekedar untuk mencontek tau hanya melihat hasil jawaban dari kelompok lain. Diberlakakukannya kesepakatan di awal 
kegiatan untuk menjaga ketertiban siswa selama proses pembelajaran, untuk siswa yang kurang aktif, guru terus memotivasi siswa agar mau terlibat aktif dalam pembelajaran selanjutnya guru hanya menujuk salah satu kelompok untuk mempresentasikan hasilnya di depan kelas.

\section{KESIMPULAN}

Berdasarkan hasil analisis penelitian tindakan kelas dalam upaya meningkatkan motivasi belajar siswa melalu model pembelajaran Two Stay-Two Stray (Dua Tinggal Dua Tamu) pada mata pelajaran pendidikan pancasila dan kewarganegaraan disimpulkan bahwa :

1. Pada Penerapan model Two Stay-Two Stray (Dua Tinggal Dua Tamu) terlaksana dengan baik. di kelas AP 2 SMK Pasundan 1 Kota Serang.

2. Motivasi belajar siswa dengan menggunakan model pembelajaran Two Stay-Two Stray (Dua Tinggal Dua Tamu) mengalami peningkatan yang diperoleh siswa. Padasiklus I 40,10\%, siklus II $57,82 \%$, dansiklus III $81,95 \%$, terus mengalami peningkatan dengan signifikan.

3. Hambatannya yaitu memerlukan alokasi waktu yang lebih banyak pada penerapan model pembelajaran Two Stay-Two Stray (DuaTinggalDuaTamu).
4. Solusi dalam menyampaikan materi pembelajaran dilaksanakan dua kali pertemuan supaya dalam menerapkan model pembelajaran bisa dilakukan dengan waktu yang cukup. Guru telah membagi waktu kegiatantah apan-tahapan model Two Stay-Two Stray (Dua Tinggal Dиа Тати) dengan jelas dan proporsional, pembentukan kelompok sudah di buat oleh guru supaya dalam membagi kelompok siswa tidak ribut, rute perjalanan kelompok mana dulu yang akan dikunjungi.

\section{DAFTAR PUSTAKA}

\section{a. Buku}

B Uno Hamzah dan Nurdin Mohamad.2013. Belajar denagn pendekatan PAIKEM.Jakarta. PT.Bumi Aksara.

Lie, Anita. 2012. Mempraktikan Cooperative Learning di Ruang-Ruang Kelas. Jakarta: Grasindo.

Ristasa, R dan Prayitno. 2007. Panduan Penelitian Tindakan Kelas. Purwokerto: UPBJJ Purwokerto.

Suryasubrata, S. 2015. Psikologi Pendidikan. Jakarta: Raja Grafindo

Winataputra, U, dkk. 2008. Teori Belajar dan Pembelajaran. Jakarta: Universitas Terbuka. 